\title{
Planning, Justice and LGBT Urban Politics in Tel-Aviv: A Queer Dilemma
}

\author{
Chen Misgav \\ The Open University. Literature, Linguistics and the Arts Department \\ chenmisg@tauex.tau.ac.il
}

\begin{abstract}
The paper discusses planning policies and urban politics, their relation to LGBT communities in the city, and their potential to promote spatial justice within the local planning policies. The paper briefly reviews the main theoretical issues discussed in the literature regarding the connection between planning and sexuality. It also reviews three theoretical concepts of justice that relate to planning policy and urban politics: distributive Justice, procedural justice and recognition. The case study of the Gay Center at Tel Aviv's Meir Park is analyzed with reference to these three spatial justice concepts. The main argument is that the center is a clear example of distributive and procedural justice. However, when we analyze this case study in light of the concept of recognition, the findings are somewhat ambiguous. On the one hand, the case of the Gay Center indicates growing recognition of Tel Aviv's LGBT community. On the other hand, a queer analysis shows that this recognition is partial as it is limited to certain parts of the community and to spaces frequented by LGBTs in Tel-Aviv.
\end{abstract}

Keywords: planning; justice; urban politics; LGBT community; queer; Israel

Resum. Planejament, justicia i politica urbana LGBT a Tel-Aviv: un dilema queer

El document discuteix les polítiques de planificació i la política urbana, la seva relació amb les comunitats LGBT a la ciutat i el seu potencial per promoure la justícia espacial dins de les polítiques de planificació locals. El document revisa breument els principals temes teòrics tractats a la literatura sobre la connexió entre planificació i sexualitat. També es revisen tres conceptes teòrics de justícia relacionats amb la política de planificació i la política urbana: la justícia distributiva, la justícia processal i el reconeixement. L'estudi de cas del Centre Gai al Parc Meir de Tel-Aviv s'analitza amb referència a aquests tres conceptes de justícia espacial. L'argument principal és que el centre és un clar exemple de justícia distributiva i processal. No obstant això, quan analitzem aquest cas a la llum del concepte de reconeixement, les conclusions són una mica ambigües. D’una banda, el cas del Centre Gai indica un reconeixement creixent de la comunitat LGBT de Tel-Aviv. D'altra banda, 
una anàlisi queer mostra que aquest reconeixement és parcial, ja que es limita a certes parts de la comunitat i als espais freqüentats per LGBT a Tel-Aviv.

Paraules clau: planificació; justícia; política urbana; comunitat LGBT; queer; Israel

Resumen. Planeamiento, justicia y política urbana LGBT en Tel-Aviv: un dilema queer

El documento analiza las políticas de planificación y las políticas urbanas, su relación con las comunidades LGBT en la ciudad y su potencial para promover la justicia espacial dentro de las políticas de planificación local. El artículo revisa brevemente los principales temas teóricos discutidos en la literatura con respecto a la conexión entre planificación y sexualidad. También revisa tres conceptos teóricos de la justicia que se relacionan con la política de planificación y las políticas urbanas: la justicia distributiva, la justicia procesal y el reconocimiento. El estudio de caso del Centro Gay en el Parque Meir de Tel-Aviv se analiza con referencia a estos tres conceptos de justicia espacial. El argumento principal es que el centro es un claro ejemplo de justicia distributiva y procesal. Sin embargo, cuando analizamos este estudio de caso a la luz del concepto de reconocimiento, los hallazgos son algo ambiguos. Por un lado, el caso del Centro Gay indica un creciente reconocimiento de la comunidad LGBT de Tel-Aviv. Por otro lado, un análisis queer muestra que este reconocimiento es parcial, ya que está limitado a ciertas partes de la comunidad y a los espacios frecuentados por LGBT en Tel-Aviv.

Palabras clave: planificación; justicia; política urbana; comunidad LGBT; queer; Israel

Résumé. Planification, justice et politique urbaine LGBT à Tel-Aviv : un dilemme queer

Le document traite des politiques de planification et des politiques urbaines, de leurs relations avec les communautés LGBT de la ville et de leur potentiel à promouvoir la justice spatiale dans les politiques de planification locales. Le document passe brièvement en revue les principales questions théoriques abordées dans la littérature concernant le lien entre planification et sexualité. Il passe également en revue trois concepts théoriques de la justice liés aux politiques de planification et à la politique urbaine : la justice distributive, la justice procédurale et la reconnaissance. L'étude de cas du Centre gay du parc Meir de Tel Aviv est analysée en référence à ces trois concepts de justice spatiale. L'argument principal est que le centre est un clair exemple de justice distributive et procédurale. Cependant, lorsque nous analysons cette étude de cas à la lumière du concept de reconnaissance, les résultats sont quelque peu ambigus. D'une part, le cas du Gay Center indique une reconnaissance croissante de la communauté LGBT de Tel Aviv. D'autre part, une analyse queer montre que cette reconnaissance est partielle, car elle se limite à certaines parties de la communauté et aux espaces fréquentés par les LGBT à Tel-Aviv.

Mots-clés: planification; justice; politique urbaine; communauté LGBT; queer; Israël

\section{Summary}

\section{Introduction}

2. Cities, urban planning and sexuality

3. Urban planning and justice: A theoretical framework

4. Sexual politics in Israel and Tel-Aviv

5. The Gay Center in Meir Park
6. The Gay Center: Justice, planning, municipal politics and sexuality

7. Conclusion

8. Afterword

Bibliographical references 


\section{Introduction}

In October 2002, the Tel Aviv-Jaffa Municipality published a document titled "The City Profile", which concluded the first stage of developing the new statutory urban plan ${ }^{1}$. This document was a part of large-scale process in which a strategic vision for the city's development was created and published in preparation for an updated plan ${ }^{2}$. To the best of my knowledge it is the first planning document in Israeli history to refer explicitly to the LGBT community - it refers to the city's "gay-lesbian population" in the chapter "People and Society", under the subheading "Urban Social Services":

As a liberal city, [Tel Aviv-Jaffa] is open to accepting different populations, among them the gay-lesbian population. This population faces many difficulties and needs various services. Recently, the Social Services Administration developed a unique shelter for gay-lesbian adolescents who had left their homes due to their families' difficulty to accept the difference of their sons/daughters. (City Profile, 2002: 35)

Albeit referring to the LGBT community in a problematic context ${ }^{3}$ of other "special" populations, it begins with a revolutionary reference to Tel Aviv-Jaffa as a city that recognizes the community's existence and its members' right to equity in municipal service provision, making the city a pioneer in the Israeli context. This development may be attributed largely to the sociopolitical dynamics that transformed local sexual politics, as discussed in detail below (in the section dedicated to "Sexual politics in Israel and in Tel-Aviv").

The present article discusses and questions the complex connections between urban planning, urban politics towards LGBT people, and conceptions of justice, especially the concept of recognition, in relation to the LGBT community in the city of Tel-Aviv. I will demonstrate these issues in a critical discussion of one of the products of the urban planning policy toward LGBTs - the Tel-Aviv Gay Community Center in Meir Park - and show how this center clearly articulates distributive and procedural justice, on the one hand,

1. Plan TA/5000 was submitted in November 2013 and has now has reached the objections stage.

2. The two documents, "The City Profile" (2002) and "The City Vision" (2005), are part of a strategic plan adopted by the municipal planning authorities. The former concludes the first stage of consolidating the plan and draws the city's profile, while the latter defines strategic outlines for developing and realizing the city's vision. These documents have no statutory status but they have become the basis for developing the statutory urban plan, and their principles guide decision makers and planners in their work.

3. The document also refers to the "gay-lesbian" community rather than the LGBT community. The latter, more inclusive term, has gradually replaced earlier ones that focused on gays, or gays and lesbians. Another current term is "queer", used with two conventional meanings: queer as an umbrella term akin to LGBT; and queer as an anti-identity and anti-essentialist political position in the spirit of the queer theory that strives to deconstruct conventional identity definitions and to emphasize the fluidity and subversion of the concept of identities based on sexual tendency or gender (see Gross, 2015; Gross and Ziv, 2003). 
while articulating recognition justice in a complex and ambiguous fashion, on the other. The paper's central argument is that via a "queer analysis" it is possible to observe how the recognition of the LGBT community is partial and serves only certain privileged groups, while excluding and alienating others. As shown in a different context, community hegemony is constructed through conflicts, such as between members of different generations or economic status, and has to do with an increased presence of state functions (Ronsbo, 2006). This is also true for the local LGBT community hegemony, whose leaders, mainly (Jewish-Ashkenazi ${ }^{4}$ ) gay males, have strong connections both to the municipality and to governmental authorities. These connections became stronger after the 2009 murder of two young LGBTs in a Tel Aviv community club (Gross, 2015). Conversely, the hegemonic leaders of the community and the Gay Centre in particular are increasingly criticized for excluding marginalized sectors such as lesbians, transgenders or bisexuals (Eisner, 2012; Hartal, 2015; Gross, 2015), or older community members (Misgav, 2016). This political and urban reality is important to understand since it happens in the most liberal and "gay friendly" city in Israel, as elaborated on later.

This argument joins a growing literature placing more emphasis on categorizing specific groups and why urban planning policies lack the awareness of diversity complexity. At the same time, the paper reveals the success of TelAviv and its Gay Center in reaching tangible results, and as such adds value to our understanding of the pros and cons of targeting specific groups in the urban policy process.

I begin with a brief review of the literature on urban planning and sexuality followed by a discussion of the various approaches to justice and Israeli sexual politics. Next, I illustrate these issues in light of the case of Tel Aviv-Jaffa and particularly its Gay Center, the political and planning contexts that led to its establishment, and its significance for the local LGBT community.

\section{Cities, urban planning and sexuality}

\subsection{Sexuality and the city}

Although homosexual activities have been part and parcel of big city life since ancient times (Higgs, 1999; Cook and Evans, 2014), gay sexuality has been perceived in the modern west as a crime and a perverse subversion of the social order, at least until the Stonewall Riots in 1969 (Frisch, 2002; Mort 2000). However, urban historian George Chauncey (1994) demonstrated that already by the end of the nineteenth century, a gay-lesbian world with clear spatial characteristics existed in New York, with community institutions and meeting places that helped gays and lesbians overcome discrimination and find apartments for rent, jobs and social and romantic connections. The spatial

4. The term Ashkenazi refers to European Jews. Less than half of the Jewish population in Israel is Ashkenazi (the majority are Mizrahi - people whose ethnic origin is from Muslim countries), but this group is still the economically and politically hegemonic (Swirski, 1989). 
presence and the appropriating of spaces in the city as identified with the gay community and its unique culture actually turned into political action.

In many cities, exclusion and discrimination led to a process of spatial segregation of the LGBT community and concentration in segregated neighborhoods and areas. This served two main purposes: avoiding hostile attitudes, oppression and discrimination by the external environment; and developing a unique culture by socializing individuals in the community and providing them with required services. This spatial segregation was at the center of the first spatial researches who examined the phenomenon in the local context of the neighborhood and entertainment venues (Weightman, 1980), as well as the effect of segregation on urban development (Lauria and Knopp, 1985) ${ }^{5}$.

\subsection{Space, sexuality, and the theory of planning}

Since the 1990s, geographers have studied the relation between queer theory, spatial and geographical theories (Bell and Valentine, 1995; Browne et al., 2007; Hubbard, 2012; Johnston and Longhurst, 2010), and urban politics (Andrucki and Elder, 2007; Bell and Binnie, 2004; Brown, 2008; Kenney, 2001). Very little, however, has been written about planning theories and practices. Some scholars define urban planning as "a heterosexual project," promoting spaces that exclude people based on sexual orientation by means of various planning tools (Frisch, 2002). Modern urban planning is also often described as a tool for spatial control and exclusion, and even for discrimination in allocating resources for different populations that is not necessarily sexual but, for example, ethnic-national (Yiftachel, 1998). Also missing from the literature are real-life experiences and activism that link urban policy, local politics and planning, themes that are the focus of this research. Some have adopted these claims of exclusion in reference to sexual orientations (Sandercock, 1998a), with a demand to "make the invisible visible" in the context of identities and planning, and with an emphasis on local knowledge and the needs of populations with difference (Fenster, 2004; Sandercock, 1998b). Since the mid-1990s, planning historians have broadened the field's scope to include new disciplines, previously unheard voices and fresh perspectives (Dubrow and Corbin-Sies, 2002); but only very recently has the relationship between sexuality and planning become more visible within the planning literature (Doan, 2011a, 2015a, 2015d; Maginn and Steinmetz, 2015).

In addition to these developments in the field of planning history, the planning discipline also faces growing criticism by LGBT theoreticians. This criticism includes three main thrusts: first, the way planning preserves and promotes the heterosexual order and social and family values while ignoring the

5. The abovementioned researchers and subsequent ones (Adler and Brenner, 1992; Forsyth, 2001; Johnston and Valentine, 1995; Valentine, 1993, 1995) examined the differences between lesbian women and gay men in urban spatial contexts. However, space limitations prevent me from elaborating on that distinction. 
needs of LGBTs and the way they use the urban space (Frisch, 2002); second, how planners erase spatial memory by ignoring or destroying sites connected to LGBT urban history (Doan and Higgins, 2011); and third, how they disregard the possible effects of their decisions on the LGBT communities (Doan, 2011).

This criticism poses demands to both the LGBT community and urban planners. LGBTs should ask themselves, as the feminists in the 1970s did, what a city should look like and what kind of urban vision will suit them (Frisch, 2002). Planners should ask themselves how they could have (and to a certain extent still do) disregard the needs of LGBT people (Doan, 2011). This disregard is not accidental (Doan, 2010). One of its sources is related to the perception of planning as a purely technical and professional practice, or one that relates to "normal" (heterosexual) people. This approach is related, primarily but not exclusively in the North American context, to deep-seated objection to the LGBT way of life, and even to homophobia in the professional and academic world. Another source is anti-capitalist and radical leftwing planners who see equal planning rights for LGBTs to allow wealthy gays to take over derelict neighborhoods, and to profit from their gentrification (ibid). One way or the other, it is important to stress that although LGBTs are a minority, the issues that emerge from their lives in the city are not insignificant to planning theory and practice (Forsyth, 2001). According to Petra Doan (2010), planners should rid themselves from "the tyranny of gender planning", or heteronormative planning based on narrow and dichotomous gender-oriented definitions. Thus, planners should be sensitive to LGBT people's experiences of humiliation and spatial injustice and consider the implications of their professional decisions for people with non-heteronormative orientations (Doan, 2011; Misgav, 2008).

\subsection{Planning for sexual minorities in practice}

Moira R. Kenney (2001) describes how cities such as San Francisco and Los Angeles have become Meccas for LGBTs, and the planning profession's influence on the neighborhoods they inhabit and the services they receive in the two cities. Kenney relates both to planning theory and practice and contends that both should open toward LGBT social and political movements traditionally excluded from the planning and by planners. Doan and Higgins (2011) provided a specific example of the way that planning can influence redevelopment and gentrification in the midtown neighborhood of Atlanta. Elsewhere, Doan (2015b) documented the "cleansing" of LGBTQ areas and suggested that heteronormative and urban renewal pressures underlie the purging of queer spaces in Atlanta. She also explored how planning practice has failed to consider the needs of LGBTQ-identified individuals (Doan, 2015c). Doan has recently (2016) offered some ways in which progressive planners might seek to incorporate non-normative sexualities and genders into the public domain, reduce inequality that arises due to anti-LGBTQ discrimination and provide material support to the most vulnerable members of the LGBTQ 
community. Progressive cities, thus, should recognize vulnerable populations such as LGBTQ homeless youth and transgender people and provide them with drop-in centers and training programs. Progressive cities should recognize existing queer spaces within them, such as neighborhoods familiarly known as gayborhoods or gay villages (urban areas where LGBTQ bars and businesses or residences are in proximity), and protect them from gentrification, which renders them unaffordable to younger LGBTQ people and to LGBTQ institutions (bars, businesses and community organizations). The gentrification trend is exacerbated when city officials adopt planning documents that fail to recognize the decades-long existence of the LGBTQ community in a specific location. Planners have a range of tools that might be used to recognize and preserve these unique cultural areas, including historic preservation districts, which might provide the same kind of neighborhood recognition given to ethnic neighborhoods. But recognition is only a first step. We still need to study the role of community activism and the relationship between LGBTQ communities and urban politics, and how communities can promote recognition and help make their cities safe and progressive.

One of the studies documenting such a process explored community activism and political engagement in the planning of Manchester's city center, especially its gay area (Quilley, 1997). The case of Manchester proves that real success comes when local authorities acknowledge the existence and identity of LGBT communities in the city, taking their needs into account in planning and development (in various perspectives: from housing or services provided by state agencies, to the need of safe public spaces or social and cultural needs etc.). Moreover, it proves that profound change in planning perceptions, coupled with the willingness of planners to work with LGBTQ organizations, can also survive local political changes (such as the transition from a liberal-labor municipal government to a conservative one in the period examined). The conclusion that emerges from such planning is that all parties have something to gain: the economic development succeeded and the city became a LGBT tourist destination; the city's physical appearance and its safety improved, and the reconstruction of the gay quarter projected on the nearby neighborhoods. Politically, community members who had hitherto been excluded from the political system were now able to enter it, so that the planning process proved to be conducive to political equality.

Some scholars have now written directly with issues of governance and planning in other parts of the world. Ruez (2016) examined a series of projects convened by the City of Sydney council between 2010 and 2013 that were intended to address issues faced by queer people from "culturally and linguistically diverse" communities. He argued that these efforts carved out spaces in which racialized queer people in Sydney could appear politically and in which the uneven geographies produced by the mutually constitutive regimes of sexuality and race could become an object of differentially shared concern. Some scholars (Fincher and Iveson, 2008; Fincher et al., 2014) discussed the politics of recognition and inclusion, including for the LGBTQ communi- 
ties, and show how multicultural planning does in fact work. They suggested three social logics (redistribution, recognition and encounter) that would better ensure that all city residents can participate in the just city. Finally, scholars recently discussed some ways in which the needs of LGBTQ minorities might be better accommodated in planning processes (Gorman-Murray, 2011; Gorman-Murray and Nash, 2014; Nash and Gorman-Murray, 2015; Prior and Gorman-Murray, 2015). For example, Gorman-Murray (2011) points to how each state has specific 'social planning' regulations. Then most delegate the social planning dimensions to local government areas (local councils; LGAs). In NSW, for example, the local government planning regulations changed in 2012. In Sydney, the two councils that have solid planning/practice on LGBT communities are the City of Sydney Council.

\section{Urban planning and justice: A theoretical framework}

"Justice" in Latin means fair allocation of resources. By extension, social justice is also distributive justice, but many also stress the value of liberty (Dahan, 2007; Yasour, 2003), or democracy that serves simultaneously as a means and component of distributive justice, and a component of justice itself, political justice (Marcuse, 2014). Being part of a public system, spatial justice is required, and the contribution to the general public constitutes one of the major justifications for the existence of planning systems on the national and local levels (Alfasi and Fenster, 2014). Three aspects of justice are relevant for our purposes: distributive, procedural and recognition, and each will be discussed in turn.

Different researchers from the planning field dealt with the question of justice. For example, "collaborative planning" (Healey, 1997) demands recognition of the different identities involved in the planning process in order to render it more "just". The claim is that a broad meaning of justice in planning requires broadening the range of participants (Campbell, 2006), and also recognizing their needs and identities (Fainstein, 2010). These issues are part of the present discussion on the "just city" (Fainstein, 2010; Marcuse, 2012). According to Peter Marcuse (2014), the just city is not only one where affordable housing and expensive housing are available to all under a certain standard of distributive justice, but also one which supports diverse needs, ambitions, and ways of life. Such all-inclusive social justice, that also includes distributive justice in its broad and democratic meaning, is the basic purpose of human existence in the urban space, as described for the first time in the urban planning context by David Harvey (1973), and later by Susan Fainstein (2010) and Peter Marcuse (2012).

In the urban and political reality, disagreements regarding the planning implications of justice affect the public planning system's ability to operate in the spirit of the philosophical justice principles. In this context, Arza Churchman (2012) raises the issue of procedural justice for groups of population who are at the planning system's margins. For her, procedural justice means 
resolving public issues by facilitating public participation in planning decision making processes, including marginal groups, such as the LGBT community. According to Churchman, procedural justice complements distributive justice but does not necessarily lead to it, as planning that suits the needs of one group might come at the expense of the needs of another.

Other researchers (e.g. Rosner, 2003) call the struggle of groups and individuals to promote their rights and needs "politicization of needs". Defining needs and struggling to achieve them in urban planning contexts require awareness and recognition of rights. Thus, recognition politics is integral to identity politics that also involves redistribution, or as Nancy Fraser claims, "Justice requires nowadays a distribution and recognition" (2004, 271). Fraser challenges the dichotomy of cultural politics of recognition, as part of the LGBT identity politics, for example, and on the other hand, socioeconomic politics of resource redistribution. She believes that an appropriate and comprehensive theory of justice should include components of both, based on recognition of two kinds of injustice: distributive, that is, unequal distribution of resources; and recognition, that is, lack of recognition of the cultural identity of certain groups by the establishment (ibid). These issues will be examined in light of the case study of Tel Aviv's Gay Center.

\section{Sexual politics in Israel and Tel-Aviv}

The Israeli LGBT community has gone through significant changes since the late 1980s. Before that time, Israel was a conservative place for LGBTs and in many ways excluded them from the public sphere. The turning point was the amendment of the penal code that prohibited homosexual intercourse. This penal code was borrowed from British law and although very rarely enforced, its amendment in March 1988 heralded a revolutionary decade (Harel, 1999). LGBT identity began being recognized not only legally but also in the media and in other symbolic spaces within Israeli society, such as the military (Kama, 2000, 2011).

In the 1990s, Tel Aviv became Israel's gay capital, and unlike the official capital, Jerusalem, began supporting the LGBT community (Alfasi and Fenster, 2005; Fenster and Manor, 2010; Kama, 2011). The local gay scene flourished and began attracting growing numbers of gay tourists and venues (Kama, 2014). Tel Aviv also led the way in LGBT municipal representation: in 1998 the first lesbian politician, Michal Eden, was elected to the municipality ${ }^{6}$. Since then, LGBTS have been elected to all city councils in Tel Aviv, and most recently, in 2014 three gay representatives were elected. This development changed both the public visibility and legal status of LGBTs in Israel.

6. The first Lesbian women to be elected to office in the Israeli political system was Marcia Freedman, who was a Knesset (parliament) member during the 1970s, but she "came out" as a lesbian only later when she was no longer a public figure (see her memoir: Freedman, 1990). 
A cautionary note is in order here, however. These "rights" achieved by the Israeli LGBT community are controversial given the broader context of the Israeli-Palestinian conflict. I am mindful of the growing global gay movement which views these "rights" as a form of "pinkwashing": a strategy designed to conceal the flagrant violations of Palestinian human rights behind a progressive image personified by Israeli gay life (Gross, 2015; Schulman 2012). This controversy impacts on LGBT and queer local politics and activism in the local community (Baum, 2006; Ziv, 2010) and even within the Gay Center itself (Misgav, 2015, 2016).

\section{The Gay Center in Meir Park}

In January 2008 the LGBT Community Center ("Gay Center") was opened in Tel Aviv's Meir Park. Its opening is connected and has contributed to the gay community's growing influence in the city (Kama, 2000), resulting in increased allocation of municipal resources and services. This change in local politics and planning is evident in the findings of two surveys of the LGBT community. At the beginning of the previous decade two large-scale surveys were carried out to identify the community's needs. The "pink" survey, initiated by the city council member Michal Eden and conducted by the Center for Economic and Social Research in the Municipality of Tel Aviv (see, Balnero and Fridman, 2001), was designated "to collect information about the ways of life, the social stances and the entertainment habits of the gay-lesbian community members, in order to help the committee for the LGBT and Tel Aviv municipality in their activities for the community" (ibid, no page number). In 2004, council member Itay Pinkas conceived the LGBT community center, which led to a "needs survey toward the establishment of a city center for the LGBT community" (Pizmony-Levi, 2005).

This recent tendency toward recognizing the needs of the LGBT community in the city, and the resulting redistribution of resources, are also related to globalization processes that have weakened the state and its institutions, and strengthened municipal autonomy in certain areas, sometimes to the point of acting against national policies, for example regarding the LGBT community (Alfasi and Fenster, 2005). Alfasi and Fenster contend that in this context that the Municipality of Tel Aviv is the only official institutional body in the state that acknowledges the existence of a gay-lesbian community with special needs and provides it with the municipal services needed (ibid). The process of negotiation between the community and the municipality, and the latter's growing autonomy, culminated in the decision to establish a community center at the municipality's initiative and with municipal funds.

The center is located in a three-story former school building owned by the municipality at the edge of the park, in the heart of the city. Its director Yuval Egartt says that the process of establishing the center began in 2004 for two practical reasons: a major increase in the activity of community organizations such as Hoshen (the lectures and educational service of the Israeli 
LGBT Association) and IGY (Israeli Gay Youth), and a severe lack of space for the activities of organizations, particularly for administrative purposes. Egartt describes the coincidence in choosing the building and its allocation for the center, despite the great investment in the preceding surveys:

We suffered from a real lack of physical space, of offices for the community's organizations... In 2005 I received keys for a kindergarten... in Ramat-Aviv [wealthy northern neighborhood] - they gave us a kindergarten of two classes and budget to renovate the place. And then, a week before the renovation started I received a call from the Director of the Education Department... saying: "Stop the renovation, we don't have enough kindergartens and we have to take this one back. We will give you another place but right now we need the keys urgently". The Department for Strategic Planning and the Engineering Administration asked us what we needed. We did not have our needs documented and we did not know what we needed... So we started a one-year process and we had options for three buildings... This is the historical mistake that led us to Meir Park, otherwise we would have remained long ago in Ramat Aviv. (Interview, August 17, 2011)

Nowadays, the center includes an information center, activity rooms, a performance hall, coffee shop, and clinic for the LGBT community. It also serves as the headquarters of many community organizations that used to be scattered in different places. About half of the funding comes from the center's revenues (office rentals, the coffee shop license and minimal participation fees for activities); the other half is provided by the municipality (about $10 \%$ by direct support and the rest as salaries and other transfers); a small additional sum is donated. The model of the Gay Center is unique and innovative on a global scale, as although social community centers for the LGBT exist in many cities in the west, they are mostly operated exclusively by NGOs with no direct connection to the municipality or any other authority (Andrucki and Elder, 2007), even though they often receive some sort of financial support from the municipality. In the Israeli case, the connection between the municipality and the center is not limited to the use of the municipal building and the budget transferred to a joint management and also to salaries for the center's employees, but is also embodied in the fact that the center was founded by the municipality to serve the community all over the city and even beyond it, unlike other centers that serve a geographical community (a neighborhood for example).

That being said, criticism was soon voiced within the community that the center had become a hegemonic hub dominated by Ashkenazi middle-class gay men. Called queer patriarchy (Nast, 2002) ${ }^{7}$, such criticism is quite common in global LGBT communities, and is voiced mostly by marginalized groups such as lesbians, transgenders, bisexuals and others, who feel excluded from the commu-

7. This patriarchy includes mainly white well-to-do gay men belonging to the "creative class" (Florida, 2004); it is connected to the establishment and to patterns of capitalistic and global consumerism and replaces older, heteronormative patriarchies such as family, and racial and militaristic attitudes. 
nity leadership. In this specific case, it is strongly linked to the Gay Center's close and unique connections to the municipal establishment, connections that many see as promoting neoliberal practices and reproducing communal hegemony (Moreno, 2011), thereby excluding certain LGBT groups from decision making. I will elaborate on this important issue in the next section.

\section{The Gay Center: Justice, planning, municipal politics and sexuality}

In this section I revisit the three types of justice in the context planning, municipal politics and sexuality. I will demonstrate that while the meanings of distributive and procedural justice are relatively simple and clear, the meanings of recognition justice require deeper and more nuanced discussion.

Let us return to the quotation from "The City Profile" with which I opened this article. This document's trailblazing approach to the LGBT community cannot be taken for granted, and as demonstrated above, urban and planning authorities' recognition of gender and sexual communities and their planning needs is a relatively new phenomenon - certainly in the Israeli context. As suggested above, Tel Aviv-Jaffa leads a fairly independent policy (Alfasi and Fenster, 2005), fundamentally different not only from that of the national government (Ministry for the Interior, for example), but also from what happens in other major cities ${ }^{8}$. Beside the document's recognition value, I would like to examine whether this policy also embodies distributive justice toward the LGBT in the city. The document was published about a year after the municipality had conducted the first extensive official survey of the needs of the LGBT community in the city (Balnero and Fridman, 2001). Although this survey was abandoned and its findings were not adopted or published, the municipality chose a strategy of recognition of the LGBT community in the city, also involving the budgeting of a community center - again, an exceptional phenomenon in the Israeli context.

This urban strategy led to the second survey (Pizmony-Levi, 2005), designed to (1) characterize the different needs of members of the LGBT community and receive their feedback; (2) examine the need for a dedicated city center; and (3) characterize the center's predictable uses from the sociodemographic aspect and specify its service offerings accordingly (ibid, 14). The decision to invest in conducting the surveys in preparation for a much larger investment in establishing the Gay Center points to a distributive policy that turns the LGBT community from an invisible to a legitimate community?.

8. In Jerusalem, for example, municipal authorities consistently refuse to support and even acknowledge the LGBT community and local NGOs struggle every year for equal distribution of resources or the right to public space (e.g. the gay parade) (See Elad, 2005; Alfasi and Fenster, 2005).

9. In the last decade there has also been criticism within the community about not getting enough budgets and being discriminated in comparison to other communities. While I cannot elaborate here on this criticism, suffice it to say that it does not detract from the unique achievement embodied by the center. 
In addition to distributive justice, does the process described above promote procedural justice in the planning context? I argue that the decision to invest resources in the center and prepare it for a participatory process is a manifestation of procedural justice for the LGBT community. True, deeper community participation beyond the needs surveys and the municipality's joint work with community representatives could have been attempted, and naturally those representatives represent the more powerful and mainstream sections of the community. Still, the process embodied, to a large extent, the principles of procedural justice in planning.

As for the third type of justice - recognition justice - it is obvious that the municipality's policy with its distributive and procedural justice aspects deliberately promoted unambiguous recognition of the LGBT community as part of Tel Aviv-Jaffa's population. However, the issues here are less clearcut. The first issue in this context is related to transferring LGBT activities from informal queer spaces to more "legitimate" ones such as the Gay Center. Over the years, before the official recognition of the LGBT community, its members would meet and interact in "gray" and marginal urban spaces that served as a basis for empowerment, identity-building and organizing, similar to other communities (Yiftachel, 2012), including political protest organizations (Castells, 1983). Such spaces might be entertainment venues (Chauncey, 1994; Weightman, 1980), or places for sexual encounters and "cruising", such as parks (Hirsch, 2005). Parts of the LGBT community tend to view the establishment's recognition as disciplining, controlling and restricting the spaces of action of individuals in the community, and as a move to normalize and mainstream them, and prevent non-heteronormative use of space that is still considered by many as perverse and obstructive of public order (Hubbard, 2012; Mort, 2000). In the specific Israeli context, recognition by the establishment is considered by many LGBTs as serving the Jewish national project (homonationality) and presenting Israel in the world as a paradise of human rights, thus "pinkwashing" its crimes in the Occupied Palestinian Territories (Gross, 2015). Others argue that the Gay Center represents Zionist and national "good citizenship" (Hartal and Sasson-Levi, 2017), in the sense of cooptation with the state. Homonationalism refers to dynamic binary processes of inclusion and exclusion in which specific groups are marked with the "correct" belonging and are deemed legitimate, while others are distanced from the public sphere and deemed perverse. In other words, inclusion in mainstream society also involves exclusion by ignoring inequality towards sections of the LGBT community (Hartal and Sasson-Levy, 2018; Puar, 2007; Schotten, 2016). Aeyal Gross (2015) argues that even though many Israeli LGBT people believe that they live in a liberal democratic state, this notion is actually exploited as a manipulative differentiation of Israel from other Middle Eastern countries and reflects their lived realities in a limited and narrow way only. This politics is named "pinkwashing", a strategy of camouflaging human rights violations, specifically towards Palestinians, via liberal and progressive visuals of civil and LGBT rights (Schulman, 2012). The discourse of homonationalism, Gross 
contends, should also "examine how homosexuals (at least some) use the state and the nationalism discourse similarly to how the state uses homosexuality" (2015: 143).

Indeed, for many years before the opening of the center, Meir Park was known as a place for forbidden relationships, secretive love affairs, misdemeanor and crime (Bileski, 2011), as well as a nighttime meeting space for gays, especially for sexual purposes (Allweil, 2011). Note that at about the same period of the surveys preceding the founding of the center, a renovation of the park was completed. It was planned for three main target populations: children, senior citizens and dogs owners. Gay males did not participate in the preliminary process of defining the needs served by the renovated park, and their needs were thus disregarded. The park that used to be dark and thick with vegetation became open-spaced and lit at night, thus putting an end to its sexual usefulness (Allweil, 2003).

The park's renovation demonstrates how, initially, procedural justice did not materialize for the LGBT community. On the other hand, few years later the park received a different symbolic meaning for the LGBT community, more "institutional" and legitimate, when the Gay Center came into being with its public events (such as the Pride Parade that starts there every year), its coffee shop, and memorial monuments ${ }^{10}$. In other words, official recognition of certain LGBT activities, such as the activities offered within the gay center and supported by the municipality and the LGBT community hegemony, as legitimate and deserving institutional support was counterbalanced by the exclusion of activities considered less normative, such as cruising in the park after dark for meetings and sex.

The second issue is related to the urban policy and planning politics adopted by the municipality, designed to promote Tel Aviv-Jaffa's image as a modern city, part of a global network of financially and culturally leading cities (Kippnis, 2009). Part of this positioning includes policy for the encouragement of activities by the so-called "creative class" (Alfasi 2006). This is a global phenomenon that has recently become prevalent among planners and urban decision makers (Muller-Myrdahl, 2011). These ideas draw on Richard Florida's (2004) creative cities theory that emphasizes the assimilation of politics of difference and making the city's differences visible as part of the process of turning it into a creative, global, attractive and competitive destination. In other words, a population with difference is now considered an advantage, and investing in it, a wise economic decision.

This new embracing of the LGBT community by urban decision makers and planners worldwide, and particularly in Tel Aviv-Jaffa, makes sense from their perspective as the LGBT community is commonly considered a creative population (Alfasi and Fenster, 2005). Thus, on the surface it would seem that

10. One monument commemorates LGBT victims of Nazism, and a cactus garden was planted in the memory of Liz Tobishi and Nir Katz who, murdered in 2009 in an attack against a gay youth club in Tel Aviv. 
promoting sexual difference and its visible urban presence advances recognition justice for the LGBT community, and meets the Fraser's (2004) distributive justice requirements. However, a queer analysis raises the possibility that this kind of recognition justice can be problematic and complex more than it seems at first glance. In order to understand this point we need to analyze the urban strategy in respect to queer theory that challenges its basic assumptions, as I will show here in details.

Such urban strategy, especially when accompanied by planning policy that aims to acknowledge sexual difference and meet the needs of the diverse LGBT community requires a stable, categorical identity with political visibility and representation; that is, an essentialist identity acceptable to the mainstream, or at least one that does not explicitly challenge the existing consumerist and social order (Muller-Myrdahl, 2011). This is problematic from the queer point of view that perceives sexual identity as a fluid category, unfixed and unstable, not necessarily heteronormative or homonormative. Lisa Duggan (2002, 179) gave homonormativity a political meaning, and associated it with neoliberalism: "Politics that does not challenge the institutions and the accepted heteronormative assumptions but confirms them, as a part of privatized, nonpolitical gay culture that is rooted in the domestic individual space and in consumer practices". Dianne Richardson (2005) calls homonormative sexual politics "politics of normalization", meaning, neoliberal politics that strive for equality and assimilation in mainstream heterosexual society (on the urban, national and even global level).

Thus, the queer outlook on the realization of recognition justice in the Tel Aviv Jaffa's planning policy criticizes the fact that it "hugs" the LGBTs, expects them to be "presentable" and "good citizens" (Hartal and SassonLevi 2017), and limits them to institutional spaces and certain activities. This queer perspective does not detract from the importance of fairer distribution of resources (distributive justice), with the participation and cooperation of the LGBT community in planning and policymaking (procedural justice), but at the same time objects to the neoliberal view of LGBTs as consumers with an essentialist identity. It asks why justice must necessarily turn the Other into an obedient consumer and poster person for tourism promotion. The Gay Center is an obvious embodiment of these neoliberal values (Moreno, 2011) and represents the establishment's way of rewarding the LGBT community for their (economic and political) cooperation - particularly its wealthy, Ashkenazi and well-connected gay men, or the local queer patriarchy (Nast, 2002). Queer criticism questions the center's potential contribution to the general LGBT community: is it no more than neo-corporatism (Hasson, 2001) municipality-sponsored activism? On the other hand, the Gay Center and the local queer patriarchy it represents are not one-dimensional and can give rise to subversive groups that undermine the homonormative order, such as queer groups, transgenders or bisexuals, indicating that the issue of recognition justice in the context of the Gay Center is complex and not amenable to simplistic generalizations (Misgav, 2015, 2016). 


\section{Conclusion}

This article presented issues arising from the interrelations between planning, municipal politics and sexuality, an issue that needs better understanding in order to generate cities more inclusive of sexual diversity. On the one hand, it is a timely research project given the promotion of the concept of progressive cities, where the presence of sexual minorities is conflated with economic growth. On the other hand, the emergence of conservative politics continues to play out in different ways across the world. For example, highlighting the importance of this research are the anti-gay and anti-trans violence worldwide, protests against gay pride events (in Russia, Poland, Hungary and other places), or hate crimes such as the massacre at the gay nightclub in Orlando or the murders in the gay youth club in Tel-Aviv (2009) or during the gay pride parade in Jerusalem (2015).

In this paper, I examined some theoretical aspects and definitions of justice in its urban and planning context - distributive, procedural and recognition justice - through the case study of Tel Aviv-Jaffa and specifically the municipal Gay Center. The case study demonstrated that establishing the center promoted both distributive and procedural justice. The discussion of recognition justice gave rise to a greater complexity given the institutionalization dilemma, or, in this case, the queer dilemma. As we have seen, the center transformed the relationship between the local (and even national) establishment and the LGBT community, and in fact promoted recognition of an essentialist, mainstream national(ist) and consumer(ist) LGBT identity, to the exclusion of other sectors of the community and the spaces that served them.

\section{Afterword}

Very recently, in August 2019, the Tel-Aviv's residents and the LGBT community were invited to a public event within the gay center. The aim of this event, which was accompanied by publications in the local and national media, was to celebrate the decision of Tel-Aviv municipality to allocate 30 million NIS (about 8.5 million US\$) for a serious renovations and expansion of the gay center and rebuilt it (in the same location), and to present to the public and the LGBT community the proposed program and the planned design of the new center, which is expected to be open during the pride week of 2020 (June 2020). The program was based on the results of a public participation process that were done with the users of the gay center and with other LGBT community members during March and April 2018, headed by the Tel-Aviv Municipality public participation unit and private planning office (DY Common Planning) hired for this purpose. This progression reflects the growing political power of the LGBT community and its representatives within the local politics on the one hand, and the successful of the gay center itself, that can no longer provide the spaces and services the city and the community need. On the other hand, it is a direct continuity of the process that led to the 
opening of the gay center, just a decade before, and thus strengthens the argument and analysis presented in this research. Of course, this news will need a better elaboration and analysis that are beyond the scope of this paper, but they do reflect a tendency indicate the current relationships between political powers, planning issues and LGBT community in Israel and in Tel-Aviv these days.

\section{Bibliographical references}

Adler, S. and Brenner, J. (1992). "Gender and space: Lesbians and gay men in the city". International Journal of Urban and Regional Research, 16, 24-34.

Alfasi, N. (2006). "Creative cities: Jerusalem, Tel Aviv and the new economy". Israeli Sociology, 8 (1), 29-64 (Hebrew).

Alfasi, N. and Fenster, T. (2005). "A tale of two cities: Jerusalem and Tel Aviv in an age of globalization". Cities, 22 (5), 351-363.

- (2014). "Between socio-spatial and urban justice: Rawls' principles of justice in the 2011 Israeli Protest Movement". Planning Theory, 13 (4), 407-427. $<$ https://doi.org/10.1177/1473095214521105>

AllWEIL, Y. (2003). "Why did they turn off the lights in Electricity Park?". In: MoriA, Y. and BARNIR, S. (eds.). In the Public Domain: A Tribute to Tel Aviv's Municipal Gardener Avraham Karavan. Tel Aviv: Tel Aviv Museum, 101-105 (Hebrew).

ANDRUCKI, M. and ElDER, G. S. (2007). "Locating the state in queer space: GLBT non-profit organizations in Vermont, USA". Social and Cultural Geography, 8 (1), 89-104.

Bell, D. and Valentine, G. (eds.) (1995). Mapping Desire: Geographies of Sexualities. London: Routledge.

Balnero, R. and Fridman, A. (2001). The Pink Survey. Tel Aviv: The Center for Social and Economic Research in Tel Aviv-Jaffa Municipality (Hebrew).

BAUM, D. (2006). "Women in black and men in pink: Protesting against the Israeli occupation". Social Identities, 12 (5), 563-574.

BeLL, D. and BINNIE, J. (2004). "Authenticating queer space: Citizenship, urbanism and governance". Urban Studies, 41 (9), 1807-1820.

BILESKI, L. (2011). "'Before that we did not trespass': The city, the woman and the drifter in the Yaakobowitz Trial". The Law: Law Review, 16 (1-2), 131-172 (Hebrew).

BROWN, P. M. (2008) "Working political geography through social movements theory: The case of gay and lesbian Seattle. In: Cox, K.; Low, M. and RoBinSON, J. (eds.). The SAGE Handbook of Political Geography. Thousand Oaks, CA: Sage, 285-304.

Browne, K.; Lim, J. and Brown, G. (eds.) (2007). Geographies of Sexualities: Theory, Practices and Politics. Farnham and Burlington, UK: Ashgate.

CAmpbell, H. (2006). "Just planning: The art of situated ethical judgment". Journal of Planning Education and Research, 26, 92-106.

CAstells, M. (1983). The City and the Grassroots. Berkeley: University of California Press.

ChaunceY, G. (1994). Gay New York: Gender, Urban Culture, and the Making of the Gay Male World, 1890-1940. New York: Basic Books.

Cook, M. and Evans, J. V. (2014). Queer Cities, Queer Cultures: Europe since 1945. London and New-York: Bloomsbury.

Churchman, A. (2012). "Protecting groups at the margins of the planning system: Procedural justice as a means". In: HASSON, S. (ed.). Shaping the Space in Israel: The Map of Lands and Settlements. Jerusalem: Keter and JNF, 289-300 (Hebrew). 
Dahan, Y. (2007). Theories of Social Justice. Tel Aviv: Tel Aviv University and Ministry of Defense, The Broadcast University (Hebrew).

DoAN, P. L. (2010). "The tyranny of gendered spaces: Reflections from beyond the gender dichotomy". Gender, Place and Culture: A Journal of Feminist Geography, 17 (5), 635-654.

- (ed.) (2011). Queerying Planning: Challenging Heteronormative Assumptions and Reframing Planning Practice. Farnham and Burlington, UK: Ashgate.

- (2015a). Planning and LGBTQ Communities: The Need for Inclusive Queer Spaces. Abingdon: Routledge.

- (2015b). "Regulating adult business to make spaces safe for heterosexual families in Atlanta". In: Maginn, P. J and Steinmetz, C. (eds.). (Sub)Urban Sexualities: Geographies and Regulation of the sex Industry. Abingdon: Routledge, 197-218.

- (2015c). "Planning for sexual and gender minorities". In: BURAYID, M. (ed.). Cities and the Politics of Difference: Multiculturalism and diversity in Planning. Toronto: University of Toronto Press, 135-158.

- (2015d). "Beyond queer space: Planning for diverse and dispersed LGBTQ populations". In: DoAn, P. (ed.). Planning and LGBTQ Communities: The Need for Inclusive Queer Spaces. Abingdon: Routledge, 251-259.

- (2016). "Is there a place in the progressive city for the LGBTQ community?". Progressive City (16 Oct, 2016), available at: <http://www.progressivecity.net/single-post/2016/10/05/IS-THERE-A-PLACE-IN-THE-PROGRESSIVE-CITYFOR-THE-LGBTQ-COMMUNITY>

DoAn, P. L. and Higgins, H. (2011). The demise of queer space? Resurgent gentrification and LGBT neighborhoods. Journal of Planning Education and Research, $31(1), 6-25$.

Dubrow, G. and Corbin-Sies (2002). "Letting our guard down: Race, class, gender and sexuality in planning history". Journal of Planning History, 1 (3), 203-214.

Dubrow, G., Knopp, L. and Brown, M. (2015). "Act Up versus Straighten Up: Public Policy and Queer Community-Based Activism”. In: DOAN, P. (ed). Planning and LGBTQ Communities: The Need for Inclusive Queer Spaces. Abingdon: Routledge, 202-216.

DugGan, L. (2002). "The new homonormativity: The sexual politics of neoliberalism”. In: R. CAStronovo and D. D. Nelson (eds.). Materializing Democracy: Towards a Revitalized Cultural Politics. Duke: Duke University Press, 175-194.

EgerTT, Y. (2007). The City Center for the LGBT Community: Social-Physical Program. Tel Aviv: Tel-Aviv-Jaffa Municipality, Administration of Education, Culture and Sport (Hebrew).

EISNER, S. (2012). "Love, rage and the occupation: Bisexual politics in Israel/Palestine". Journal of Bisexuality, 12 (1), 80-137.

ElaD, H. (2008). "In Jerusalem, separation walls are visible from the route of the Pride Parade". In: Katz, Y., Degani, Z. and Gros, T. (eds.). Somewhere Here: Language, Identity, Place. Tel Aviv: Hakibbutz Hameuchad, 252-276 (Hebrew).

Fainstein, S. (2010). The Just City. Ithaca: Cornell University Press.

Fenster, T. (2004). The Global City and the Holy City: Narratives on Planning, Knowledge and Diversity. London: Pearson

Fenster, T. and ManOR, I. (2010). "Homo-lesbian citizenship in the urban space of Tel Aviv and Jerusalem". Israeli Sociology, 12 (1), 7-28 (Hebrew).

Fincher, R. and Iveson, K. (2008). Planning and Diversity in the City. New York: Palgrave Macmillan. 
Fincher, R.; Iveson, K.; Leitner, H. and Preston, V. (2014). "Planning in the multicultural city: Celebrating diversity or reinforcing difference?". Progress in Planning, 92, 1-55.

Florida, R. (2004). Cities and the Creative Class. London and New-York: Routledge.

Forsyth, A. (2001). Sexuality and space: Nonconformist populations and planning practice. Journal of Planning Literature, 15 (3), 339-358.

Fraser, N. (2004). "From distribution to recognition? The dilemma of justice in the 'post-socialist era'”. In: FILK, D. and RAM, O. (eds.). The Power of Property: Israeli Society in the Global Age. Tel Aviv and Jerusalem: Hakibbutz Hameuchad and Van Leer Institute, 270-297 (Hebrew).

Freedman, M. (1990). Exile in the Promised Land: A Memoir. Ann Arbor: Firebrand Books.

FrISCH, M. (2002). "Planning as a Heterosexist Project". Journal of Planning Education and Research, 21 (3), 254-266.

GoH, K. (2015). "Place/Out: Planning for Radical Queer Activism”. In: DoAN, P. (ed.). Planning and LGBTQ Communities: The Need for Inclusive Queer Spaces. Abingdon: Routledge, 217-234.

Gorman-Murray, A. (2011). "Queering planning in Australia: The problems and possibilities of multiscalar governance for LGBT sexual minorities”. In: DOAN, P. (ed.). Queerying planning: Challenging heteronormative assumptions and reframing planning practice. Farnham: Ashgate, 129-143.

GOrman-MurraY, A. and NASH, C. (2014). "Mobile places, relational spaces: conceptualizing change in Sydney's LGBTQ neighborhoods". Environment and Planning D: Society and Space, 32 (4), 622-641.

Gross, A. (2015). The politics of LGBT rights in Israel and beyond: Nationality, normality, and queer politics. Columbia Human Rights Law Review, 46 (2), 81-152.

Gross, A. and ZIV, A. (2003). "Between theory and politics: Homo-lesbian studies and queer theory". In: KeIDAR, Y., Ziv, A. and Kaner, A. (eds.). Beyond Sexuality: A Selection of Articles in Homo-Lesbian Studies and Queer Theory. Tel Aviv: Hakibbutz Hameuchad, 9-44 (Hebrew).

Harel, A. (1999). "The rise and fall of the Israeli gay legal revolution". Columbia Human Rights Law Review, 31, 443-471.

Hartal, G. (2015). "The gendered politics of absence: Homonationalism and gendered power relations in Tel Aviv's Gay-Center". In: BrownE, K. (ed.). Lesbian Geographies: Gender, Place and Power. Aldershot, UK: Ashgate, 91-112.

Hartal, G. and SASSON-Levy, O. (2017). "Being [in] the center: Sexual citizenship and homonationalism at Tel Aviv's Gay-Center”. Sexualities, 20 (5-6), 738-761.

- (2018). "Re-Reading Homonationalism: An Israeli Spatial Perspective". Journal of Homosexuality, 65 (10), 1391-1414.

Harvey, D. (1973). Social Justice and the City. Baltimore: John Hopkins University Press.

HASSON, S. (2001). "The evolvement of neighborhood activism and the extension of citizenship rights". Israel Affairs, 7 (4), 45-64.

Healey, P. (1997). Collaborative Planning: Shaping Places in Fragmented Societies. London: Macmillan Press.

Higgs, D. (ed.) (1999). Queer Sites: Gay Urban Histories since 1600. London and New York: Routledge.

Hirsh, D. (2005). "Homotopia: Independence Park in Tel Aviv". In: KLOSH, R. and Chatuka T. (eds.). Architectural Culture, Place, Representation, Body. Tel Aviv: Resling, 287-310 (Hebrew). 
Hubbard, P. (2012). Cities and Sexualities. London and New-York: Routledge.

Johnston, L. and Longhurst, R. (2010). Space, Place and Sex, Geographies of Sexualities. Plymouth, UK: Rowman \& Littlefield

Johnston, L. and VAlentine, G. (1995). "Wherever I lay my girlfriend, that's my home: The performance and surveillance of lesbian identities in domestic Environments". In: Bell, D. and Valentine, G. (eds.). Mapping Desire. London: Routledge, 76-99.

Kama, A. (2000). "From terra incognita to terra firma: The logbook of the voyage of gay men's community into the Israeli public sphere". Journal of Homosexuality, 38 (4), 133-162.

- (2011). "Parading pridefully into the mainstream: Gay and lesbian immersion in the civil core". In: Ben-Porat, G. and Turner, B. (eds.). The Contradictions of Israeli Citizenship: Land, Religion and State. New York: Routledge.

- (2014). "Calculating hedonism among gay men". In: LEITNER M. J. and LEITNER S. (eds.). Israeli Life and Leisure in the $21^{\text {st }}$ Century. Urbana, IL: Sagamore Publishing, 281-290.

Kenney, M. R. (2001). Mapping Gay L.A: The Interaction of Place and Politics. Philadelphia: Temple University Press.

Kipnis, B. (2009). "Greater Tel Aviv as a 'global city': Hub in a global network and 'disproportional head' in Israeli space”. In: KIPNIS, B. (ed.). Tel Aviv Jaffa: From a Garden Suburb to World City: The First One Hundred Years. Haifa: Pardes, 227260 (Hebrew).

Lauria, M. and KnOOP, L. (1985). "Towards an analysis of the role of gay communities in the urban renaissance". Urban Geography, 6, 651-669.

Levin, M. (1979). Gay Men: The Sociology of Male Homosexuality. New York: Harper and Row.

Maginn, P. and Steinmetz, C. (2015) (eds). (Sub)Urban Sexscapes: Geographies and regulation of sex industry. London and New York: Routledge.

MarCuse, P. (2012). "Justice”. In: Weber, R. and Crane, R. (eds.). Oxford Handbook of Urban Planning. New York: Oxford University Press, 141-165.

- (2014). "Sustainability and justice: Goals of the cities of tomorrow". In: FENSTER, T. and Shlomo, A. (eds.). Cities of Tomorrow: Planning, Justice and Sustainability Today. Tel Aviv: Hakibbutz Hameuchad, 25-40 (Hebrew).

Misgav, C. (2008). "The urban space in Tel Aviv-Yafo as viewed by gay people". IGU- International Geographical Union, the Worldwide Conference, (Aug., 2008), Tunis, Tunisia.

- (2015a). "With the current, against the wind: Constructing spatial activism and radical politics in Tel Aviv's LGBT Community Center”. ACME: An International E-Journal for Critical Geography, 14 (4), 1208-1234.

- (2015b). "Planning, justice and LGBT urban politics: The case of Tel Aviv's Gay-Center". Tichnon - Journal of the Israeli Planning Association (special issue on planning and justice edited by Oren Yiftachel and Rani Mendelbaum), 12 (1), 180-195. (Hebrew).

- (2016). "Gay-Riatrics: Spatial politics and activism of elderly gay men in TelAviv's Gay Community Center". Gender, Place and Culture: A Journal of Feminist Geography, 23 (11), 1519-1534.

Moreno, A. (2011). Proud in the Center: Neo-Liberal Governmentality and Individualization Processes in the LGBT Community in Israel. MA thesis, Tel-Aviv University (Hebrew). 
MorT, F. (2000). "The sexual geography of the city". In: Bridge, G. and WATSON, S. (eds.). A Companion to the City. Oxford: Blackwell, 307-315.

Muller-Myrdahl, T. (2011). "Queerying creative cities”. In: DOAN, P. (ed.). Queerying Planning: Challenging Heteronormative Assumptions and Reframing Planning Practice. Farnham and Burlington, UK: Ashgate, 157-168.

Nash, C. and Gorman-Murray, A. (2015). "Recovering the gay village: a comparative historical geography of urban change and planning in Toronto and Sydney". Historical Geography, 43, 84-105.

- (2014). "LGBT neighbourhoods and 'new mobilities': towards understanding transformations in sexual and gendered urban landscapes". International Journal of Urban and Regional Research, 38 (3), 756-772.

NAsT, H. (2002). "Queer patriarchies, queer racisms, international”. Antipode, 34, 874-909.

Pizmony-Levy, O. (2005). A City Center for the LGBT Community in Tel-Aviv-Jaffa: Needs Survey Findings. Tel Aviv: The Committee for Human Rights, Tel Aviv-Jaffa Municipality (Hebrew).

Prior, J. and Gorman-Murray, A. (2015). Housing sex within the city: The placement of sex services beyond respectable domesticity. In: MAGInN, P. and STEINMETZ, C. (eds.). (Sub)Urban Sexscapes: Geographies and regulation of sex industry. London and New York: Routledge, 101-116.

PuAR, J. K. (2007). Terrorist Assemblages: Homonationalism in Queer Times. Durham, NC: Duke University Press.

Quilley, S. (1997). “Constructing Manchester's new urban village: Gay spaces in the entrepreneurial city”. In: BrENT, G. et al. (eds.). Queers in Space: Communities, Public Spaces, Sites of Resistance. Washington: Bay Press, 192-275.

Richardson, D. (2005). "Desiring sameness? The rise of a neoliberal politics of normalization". Antipode, 37, 515-535.

Ronsbo, H. (2006). "Displacing Enigma and Shaping Communal Hegemony Towards the Analysis of Violent Experience as Social Process". Dialectical Anthropology, 30 (1), 47-67.

Rosner, M. (2003). "Sociological and psychological approaches for social justice and equality in the post-industrial era". In: YAsour, A., Oved, Y., Rosolio, D., and Rosner, M. (eds.). Social Justice and Equality in a Changing World. Tel Aviv: Hakibbutz Hameuchad, 89-158 (Hebrew).

RuEz, D. (2016). "Working to appear: The plural and uneven geographies of race, sexuality, and the local state in Sydney, Australia". Environment and Planning D: Society and Space, 34 (2), 282-300.

SAnderCOCK, L. (1998a). Toward Cosmopolis. Chichester, UK: John Wiley \& Sons.

- (ed.) (1998b). Making the Invisible Visible: A Multicultural Planning History. Berkeley: University of California Press.

SCHOTTEN, C. H. (2016). "Homonationalism". International Feminist Journal of Politics, 18 (3), 351-370.

Schulman, S. (2012). Israel/Palestine and the Queer International. Durham and London: Duke University Press.

SwIRSKI, S. (1989). Israel: The Oriental Majority. London: Zed Books.

Tel Aviv-Jaffa Municipality (2002). The City's Profile: October 2002. Tel Aviv: Author (Hebrew).

- (2005). The City's Vision: May 2005. Tel Aviv: Author (Hebrew). 
VALENTINE, G. (1993). “(Hetero)sexing space: Lesbian perceptions and experiences of everyday spaces". Environment and Planning D: Society and Space, 11, 395-413.

- (1995). "Out and about: Geographies of lesbian landscapes". International Journal of Urban and Regional Research, 19 (1), 96-111.

Weightman, B. (1980). "Gay bars as private places". Landscape Research, 24 (1), 9-16.

YAssour, A. (2003). "Theories of justice in philosophy". In: YAssour, A., Oved, Y., Rozolio, D. and Rozner, M. (eds.). Social Justice and Equality in a Changing World. Tel Aviv: Hakibbutz Hameuchad, 14-88 (Hebrew).

YiftACHEL, O. (1998). "Planning and social control: Exploring the dark side”. Journal of Planning Literature, 12, 395-406.

- (2012). "Critical theory and 'gray space': Mobilization of the colonized". In: BRENner, N., Marcuse, P. and Mayer, M. (eds.). Cities for People, Not for Profit: Critical Urban Theory and the Right to the City. London and New-York: Routledge, $150-170$.

ZIV, A. (2010). "Performative politics in Israeli queer anti-occupation activism". GLQ: A Journal of Lesbian and Gay Studies, 16 (4), 537-556. 